\title{
PEMATAHAN DORMANSI BENIH KELAPA SAWIT (Elaeis guinensis Jacq.) MENGGUNAKAN KALIUM NITRAT $\left(\mathrm{KNO}_{3}\right)$ DAN AIR KELAPA \\ (The Dormancy Breaking Of Oil Palm Seed (Elaeis guinensis Jacq.) Using potassium Nitrate $\left(\mathrm{KNO}_{3}\right)$ and Coconut Water $)$
}

\author{
Sinaga, K., Chotimah, H. E. N. C. *), Jagau, Y. \\ Jurusan Budidaya Pertanian, Fakultas Pertanian Universitas Palangka Raya \\ Telp. $081210150154 *$ e-mail : hastinwindarto@agr.upr.ac.id
}

Diterima : 25/06/2020_Disetujui : 05/02/2021

\begin{abstract}
The aim of this study were, 1) to find out and study the effect of $\mathrm{KNO}_{3}$ immersion treatment on oil palm seed germination; 2) to find out and study the effect of coconut water immersion treatment on oil palm seed germination; 3) to find out and study the interactions that occur between $\mathrm{KNO}_{3}$ immersion treatment and coconut water to oil palm seed germination. This research was conducted in July 2019 until August 2019 in the Laboratory of the Department of Agriculture Cultivation, Faculty of Agriculture, Palangka Raya University using a Completely Randomized Design with 2 factors. The first factor is the concentration of $\mathrm{KNO}_{3}: \mathrm{K} 0(0 \%) ; \mathrm{K} 1(0.2 \%) ; \mathrm{K} 2(0.4 \%) ; \mathrm{K} 3(0.6 \%)$ and the second factor is coconut water concentration, B0 $(0 \%)$; B1 $(60 \%)$; B2 $(80 \%)$; B3 $(100 \%)$. The parameters observed were first count germination, maximum growth potential, germination power, growth speed, radicle length, plumular length and dormancy intensity. The results showed that the treatment of $\mathrm{KNO}_{3}$ concentration significantly affected first count germination, maximum growth potential, germination rate, growth speed and dormancy intensity. Treatment of coconut water concentration significantly affected first count germination, maximum growth potential, germination rate, growth speed and dormancy intensity. The interaction between the treatment of $\mathrm{KNO}_{3}$ concentration and coconut water concentration had no significant effect on all observed parameters.
\end{abstract}

Keyword : Coconut water, Dormancy, $\mathrm{KNO}_{3}$, Palm oil

\begin{abstract}
ABSTRAK
Tujuan dari penelitian ini adalah untuk mengetahui dan mempelajari pengaruh $\mathrm{KNO}_{3}$, perlakuan perendaman air kelapa dan interaksinya terhadap perkecambahan biji kelapa sawit. Penelitian ini dilaksanakan pada bulan Juli 2019 sampai dengan Agustus 2019 di Laboratorium Jurusan Budidaya Pertanian, Fakultas Pertanian, Universitas Palangka Raya menggunakan Rancangan Acak Lengkap dengan 2 faktor. Faktor pertama yaitu konsentrasi $\mathrm{KNO}_{3}$ yaitu $0 ; 0,2 ; 0,4$; dan $0,6 \%$. Faktor kedua yaitu konsentrasi air kelapa yaitu $0 ; 60 ; 80$; $100 \%$. Parameter yang diamati adalah first count germination, potensi tumbuh maksimum, daya berkecambah, kecepatan tumbuh, panjang radikula, panjang plumula dan intensitas dormansi. Hasil penelitian menunjukkan bahwa perlakuan konsentrasi $\mathrm{KNO}_{3}$ berpengaruh nyata terhadap first count germination, potensi tumbuh maksimum, daya berkecambah, kecepatan tumbuh dan intensitas dormansi. Perlakuan konsentrasi Air kelapa berpengaruh nyata terhadap first count germination, potensi tumbuh maksimum, daya berkecambah, kecepatan tumbuh dan intensitas dormansi. Interaksi antara perlakuan konsentrasi $\mathrm{KNO}_{3}$ dan konsentrasi air kelapa berpengaruh tidak nyata terhadap seluruh parameter pengamatan. Perlu dilakukan pengukuran kadar air sebelum perlakuan perendaman untuk mengetahui kadar air yang sesuai untuk perkecambahan benih kelapa sawit dan untuk mempertahankan viabilitas benih.
\end{abstract}

Kata kunci : Air kelapa, Dormansi, Kelapa sawit, $\mathrm{KNO}_{3}$ 


\section{PENDAHULUAN}

Tanaman kelapa sawit (Elaeis guinensis Jacq.) merupakan salah satu jenis tanaman pertanian yang menduduki posisi penting khususnya di sektor perkebunan. Hal ini disebabkan karena dari sekian banyak tanaman yang menghasilkan minyak, kelapa sawit yang menghasilkan nilai ekonomi terbesar per hektarnya di dunia Komoditas kelapa sawit merupakan komoditas unggul di Indonesia. Kelapa sawit bisa dimanfaatkan sebagai bahan bakar pengganti minyak tanah atau sebagai bahan bakar alternatif biodiesel (Masykur, 2013).

Kelapa sawit merupakan komoditas dominan yang dikembangkan di Kalimantan Tengah. Berdasarkan data statistik perkebunan Kantor Dinas Perkebunan Kalimantan, Provinsi Kalimantan Tengah termasuk daerah yang memiliki luas areal perkebunan kelapa sawit dan potensi produksi CPO (Crude Palm Oil) yang tinggi. Luas areal tersebut sebagian besar didominasi oleh luasan Perkebunan Swasta seluas 1.072.624 ha pada tahun 2017 dari 995.728 ha pada tahun 2015 dengan total produksi CPO 3.666.727 ton pada tahun 2017 dari 3.341.513 ton pada tahun 2015 (BPS, 2017).

Untuk meningkatkan produksi tanaman kelapa sawit yang produktif, dibutukan benih bermutu. Benih yang bermutu untuk meningkatkan produktivitas Salah satu permasalahan dalam meningkatkan produksi benih kelapa sawit adalah pada tahap awal perkecambahan, dapat diketahui benih kelapa sawit memiliki kulit yang sangat keras, sehingga harus melalui perlakuan khusus agar benih dapat berkecambah lebih cepat.

Permintaan benih kelapa sawit per tahun mencapai 100-120 juta kecambah, namun produsen benih di Indonesia yang ada hanya mampu menyediakan 60-70 juta kecambah per tahun. Kekurangan pasokan benih tersebut belum mencukupi permintaan konsumen, seiring dengan permintaan benih yang terus meningkat akibat minat pengusaha dan masyarakat untuk membudidayakan kelapa sawit (Farhana et al., 2013)

Mangoensoekarjo dan Semangun (2005) menyatakan bahwa ketika baru dipanen, benih kelapa sawit mengalami dormansi dan perkecambahan alami sangat jarang terjadi.
Proses pengecambahan benih kelapa sawit sulit karena benihnya memiliki kulit yang keras sehingga benih bersifat dormansi. Dormansi merupakan suatu kondisi di mana benih tidak berkecambah walaupun berada pada kondisi optimum untuk berkecambah. Perlakuan tertentu perlu dilakukan untuk mengatasi masalah dormansi tersebut, seperti skarifikasi atau penggunaan zat kimia sehingga mempermudah masuknya air dan gas pada benih (Saputra et al., 2017).

Pematahan dormansi benih dapat dilakukan dengan beberapa cara, salah satunya yaitu dengan melakukan perendaman benih dalam Kalium Nitrat $\left(\mathrm{KNO}_{3}\right) . \mathrm{KNO}_{3}$ dapat melunakkan kulit biji, sehingga dapat dilalui oleh air dengan mudah dan dapat mengaktifkan kembali sel-sel benih yang sedang dalam keadaan dormansi menjadi lebih cepat berkecambah, terbukti dari hasil penelitian Jeminar (1984) bahwa konsentrasi $\mathrm{KNO}_{3}$ 0,3\% dengan lama perendaman 24 jam dapat meningkatkan persentase daya kecambah biji kopi Arabika mencapai 65,33\%.

Cara yang lain adalah dengan menggunakan air kelapa. Menurut Lawalata (2011) air kelapa adalah salah satu bahan alami, yang mengandung hormon seperti sitokinin, auksin dan giberelin serta senyawa lain yang dapat menstimulasi perkecambahan dan pertumbuhan tanaman. Penelitian yang terkait dengan penggunaan air kelapa untuk memicu pertumbuhan dan perkembangan embrio biji pernah dilakukan oleh Suita dan Naning (2004), yaitu pada benih Kemiri (Aleurites mollucana Wild.) yang direndam air kelapa selama 4 jam menghasilkan daya berkecambah sebesar 53,33\%.

Berdasarkan latar belakang di atas perlu dilakukan penelitian tentang pematahan dormansi benih kelapa sawit (Elaeis guinensis Jacq) dengan berbagai konsentrasi kalium nitrat $\left(\mathrm{KNO}_{3}\right)$ dan air kelapa.

\section{BAHAN DAN METODE}

Penelitian ini akan dilaksanakan di Laboratorium Jurusan Budidaya Pertanian, Fakultas Pertanian, Universitas Palangka Raya. Penelitian ini dilakukan mulai dari bulan Juli 2019 sampai dengan Agustus 2019.

Alat-alat yang digunakan terdiri atas mesin gerenda, handsprayer, jangka sorong, 
timbangan digital, gelas ukur, spatula, plastik bening, karet gelang, baskom, bak perendaman, rak pengering, sprayer, pompa angin, kipas angin, kamera, inkubator dan alat tulis. Bahan yang digunakan dalam penelitian ini terdiri atas benih tanaman kelapa sawit varietas Tenera yang berasal dari PT. Sukamandang Estate, Minamas Plantation, air, larutan $\mathrm{KNO}_{3}$, air kelapa muda, fungisida (Dithane M-45) 0,1\% dan aquades.

Penelitian ini mengggunakan Rancangan Acak Lengkap (RAL) Faktorial terdiri dari 2 faktor perlakuan dengan 3 (tiga) ulangan, masing-masing ulangan terdapat 25 benih sehingga secara keseluruan terdapat 1200 benih. Adapun taraf perlakuan yaitu faktor pertama adalah konsentrasi $\mathrm{KNO}_{3}(\mathrm{~K})$ terdiri dari 4 (empat) taraf yaitu $\mathrm{K}_{0}=$ kontrol, $\mathrm{K}_{1}=0,2$ $\%, \mathrm{~K}_{2}=0,4 \%, \mathrm{~K}_{3}=0,6 \%$. Faktor kedua adalah air kelapa muda (B) terdiri dari 4 (empat) taraf yaitu $\mathrm{B}_{0}=$ kontrol, $\mathrm{B}_{1}=60 \%, \mathrm{~B}_{2}=80 \%, \mathrm{~B}_{3}=$ $100 \%$.

\section{Pelaksanaan Penelitian}

\section{Seleksi Biji}

Biji kelapa sawit yang dikecambahkan adalah biji yang masak dan berkualitas baik yaitu biji yang diambil dari buah sawit yang sudah dipanen dan yang sudah di pertimbangkan kriteria kematangan buahnya. Kriteria kematangan buah berasal dari perkebunan dengan kriteria 5 brondolan jatuh dan buah berwarna merah. Biji diambil dari varietas Tenera. dimana permukaan kulitnya tidak cacat dan bebas dari hama dan penyakit. Biji kelapa sawit yang dipilih adalah biji kelapa sawit yang apabila dimasukkan kedalam air biji tenggelam.

\section{Skarifikasi Benih}

Benih kelapa sawit diskarifikasi untuk mengurangi ketebalan kulit biji. Skarifikasi dilakukan menggunakan gerenda mesin tepat pada bagian titik tumbuh sampai terlihat bagian embrionya. Kemudian benih kelapa sawit yang selesai diskarifikasi dicuci menggunakan air bersih agar bersih dari kotoran yang melekat pada benih.

\section{Pembuatan Larutan}

Pembuatan larutan bertujuan untuk menentukan konsentrasi larutan perlakuan. Ada 2 jenis larutan yang digunakan yaitu $\mathrm{KNO}_{3}$ dan Air kelapa. Konsentrasi $\mathrm{KNO}_{3}$ 0,2\%, 0,4\% dan $0,6 \%$ dibuat dengan cara menimbang $2 \mathrm{~g}, 4 \mathrm{~g}$ dan $6 \mathrm{~g} \mathrm{KNO}_{3}$, kemudian dilarutkan dengan akuades hingga mencapai volume $1000 \mathrm{ml}$ (volume larutan yang dipakai untuk merendam benih). Konsentrasi Air kelapa 0\%, 60\%, 80\% dan $100 \%$ dibuat dengan cara mengukur $0 \mathrm{ml}$ air kelapa muda diitambah $100 \mathrm{ml}$ air, $60 \mathrm{ml}$ air kelapa muda ditambah $40 \mathrm{ml}$ air, $80 \mathrm{ml}$ air kelapa muda ditambah $20 \mathrm{ml}$ air dan $100 \mathrm{ml}$ air kelapa muda ditambah $0 \mathrm{ml}$ air.

\section{Perlakuan Perendaman}

Benih yang selesai dicuci dengan air bersih direndam selama 24 jam dengan larutan $\mathrm{KNO}_{3}$ (sesuai perlakuan) yang telah dilarutkan. Setelah direndam dengan $\mathrm{KNO}_{3}$, kemudian dilakukan perendaman dengan air kelapa muda selama 2 jam (sesuai konsentrasi perlakuan). Kemudian benih disemprotkan dengan larutan fungisida Dithane M-45 0,1\%. Perlakuan perendaman dilakukan hanya satu kali sebelum benih diinkubasi. Perlakuan selanjutnya benih dikeringanginkan menggunakan bak pengering selama 1 jam, pengeringan ini hanya untuk mengeringkan bagian luar benih. Pengeringan ini dilakukan dengan menggunakan kipas angin yang dipasang sekitar rak pengering.

\section{Inkubasi benih}

Benih yang sudah berkecambah normal dikeluarkan dari ruang perkecambahan. Setelah dikeluarkan benih di tumbuhkan diatas rockwool untuk menghitung panjang radikula dan panjang plumula. Seleksi kecambah dilakukan hingga 5 tahap dengan selang waktu 7 hari. Benih yang belum berkecambah dimasukkan ke dalam kantong plastik dan disemprot dengan larutan Dithane M-45 0.1\%. Kantong benih tersebut dimasukkan ke ruang perkecambahan. Setelah seleksi ke-5, dilakukan perhitungan daya berkecambah (Silomba, 2006). 


\section{Variabel pengamatan}

First Count Germination (FCG)

First Count Germination ditentukan dengan menghitung persentase jumlah kecambah normal pada pengamatan terakhir perkecambahan yaitu pada saat hari inkubasi ke-42. First Count Germination dihitung dengan rumus :

$F C G=\frac{\Sigma \text { Enih yang berkecambah nomal }}{\text { E Bunih yang dikecambahkan }} \times 100 \%$

\section{Potensi Tumbuh Maksimum (PTM)}

Potensi Tumbuh Maksimum (PTM) benih merupakan persentase benih yang berkecambah sampai akhir pengamatan terhadap jumlah keseluruhan benih yang dikecambahkan. Potensi tumbuh maksimum digunakan untuk mengidentifikasi viabilitas total dari benih sawit yang diuji. Dengan rumus :

$\mathrm{PTM}=\frac{\Sigma \text { Benih yang berkecambah }}{\Sigma \text { Benih wang dikecambahkan }} \times 100 \%$

\section{Daya Berkecambah (\%)}

Daya berkecambah diukur dengan menghitung persentase kecambah normal pada pengamatan pertama sampai kelima. Perhitungan kecambah normal dilakukan 5 kali yaitu 14, 21, 28, 35 dan 42 HSI (hari setelah inkubasi). Pengamatan yang dilakukan meliputi kecambah normal, kecambah abnormal dan benih dorman.

$\mathrm{DB}=\frac{\Sigma \text { KN bit } 1+\Sigma \text { KN bit } \Sigma+\ldots+\Sigma \text { KN bit } \Sigma}{\Sigma \text { benih yang dikeambahkan }} \times 100 \%$

\section{Kecepatan tumbuh (KCT)}

Kecepatan tumbuh merupakan persentase kecambah normal per etmal. Kecepatan tumbuh ini digunakan untuk mengukur vigor kekuatan tumbuh dari benih yang diuji. Pengamatan $\mathrm{K}_{\mathrm{CT}}$ dilakukan setiap hari mulai dari hari pertama inkubasi sampai akhir masa inkubasi. Persamaan yang digunakan adalah :

$\mathrm{K}_{\mathrm{CT}}=\sum_{0}^{S n}\left(\begin{array}{l}N \\ \mathrm{t}\end{array}\right)$

Keterangan :

$\mathrm{t} \quad=$ Waktu pengamatan
$\mathrm{N} \quad=$ Persentase kecambah normal setiap waktu pengamatan

Sn = Waktu akhir inkubasi (42 hari)

$\mathrm{K}_{\mathrm{CT}} \quad=$ Kecepatan tumbuh

Etmal $=$ Waktu pengamatan $(24 \mathrm{jam})$

\section{Panjang Akar (cm)}

Pengamatan panjang akar dihitung diakhir kegiatan penelitian. Dilakukan dengan cara mengukur panjang akar dimulai dari pangkal akar sampai ujung akar. Pengukuran panjang akar dilakukan dengan menggunakan jangka sorong.

\section{Panjang Plumula (cm)}

Pengamatan panjang plumula dihitung diakhir kegiatan penelitian. Dilakukan dengan cara mengukur panjang plumula dimulai dari pangkal plumula sampai ujung plumula. Pengukuran panjang plumula dilakukan dengan menggunakan jangka sorong.

\section{Intensitas Dormansi (ID)}

Intensitas dormansi adalah persentase benih yang tidak tumbuh sampai akhir pengamatan. Benih yang terserang cendawan sebelum akhir pengamatan dan belum berkecambah (dorman) termasuk ke dalam perhitungan intensitas dormansi, sedangkan benih yang sudah berkecambah dimasukkan kedalam perhitungan PTM. Intensitas dormansi dihitung dengan persamaan :

$$
\mathrm{ID}=\frac{\Sigma \text { Eenih yang tidak tumbuh }}{\Sigma \text { Benih yang dike cambahkan }} \times 100 \%
$$

\section{Analisis data}

Analisis data dilakukan dengan analisis statistik menggunakan analisis ragam (ANOVA). Jika dari hasil analisis ragam menunjukkan pengaruh dan sangat nyata, maka dilanjutkan dengan Uji Beda Rataan berdasarkan Duncan Multiple Range Test (DMRT) pada taraf 5\%. Untuk melihat hubungan antara perlakuan dan variabel maka data yang berpengaruh nyata dianalisis regresi sederhana dengan softwere SPSS. 


\section{HASIL DAN PEMBAHASAN}

Hasil analisis variansi (ANOVA) menunjukkan bahwa perlakuan tunggal perendaman benih kelapa sawit dalam larutan KNO3 berpengaruh terhadap first count germination, potensi tumbuh maksimum, daya berkecambah, kecepatan tumbuh dan intensitas dormansi. Namun tidak berpengaruh terhadap panjang radikula dan panjang plumula. Sedangkan perlakuan tunggal perendaman benih kelapa sawit dalam larutan air kelapa berpengaruh terhadap first count germination, daya berkecambah dan intensitas dormansi. Namun tidak berpengaruh terhadap potensi tumbuh maksimum, kecepatan tumbuh, panjang radikula dan panjang plumula. Data hasil analisis setiap variabel pengamatan disajikan pada Tabel 1.

Faktor tunggal air kelapa yaitu $\mathrm{B}_{3}(100$ $\%)$ tidak berbeda nyata dengan $\mathrm{B}_{2}(60 \%)$ dan berbeda nyata dengan $\mathrm{B}_{0}(0 \%)$ dan $\mathrm{B}_{1}(60 \%)$. Namun, nilai rata-rata tertinggi pada pengamatan persentase jumlah kecambah adalah perlakuan $\mathrm{B}_{3}(100 \%)$ sebesar $18 \%$ dan terendah adalah pada perlakuan $\mathrm{B}_{0}$ sebesar $1 \%$.

Hasil penelitian menunjukkan bahwa first count germinaton (persentase jumlah kecambah) dengan perendaman air kelapa mengikuti persamaan $\mathrm{y}=0,648 \mathrm{e}^{0,0289 \mathrm{x}}$ dengan $\mathrm{R}^{2}=0,675$. Dari persamaan tersebut dapat dilihat bahwa setelah konsentrasi $100 \%$, setiap penambahan konsentrasi air kelapa $1 \%$ akan menurunkan 0,648 \% first count germination (persentase jumlah kecambah). Regresi ini menunjukkan bahwa peningkatan pemberian air kelapa dari konsentrasi $0 \%$ sampai $100 \%$ meningkatkan first count germination (persentase jumlah kecambah) sebesar 67,5\% (gambar 2). Persamaan diatas dapat disubstitusikan dengan nilai konsentrasi air kelapa $0 \%$, bahwa pada konsentrasi tersebut diperkirakan nilai first count germination yaitu sebesar 0,648 \%; pada konsentrasi $60 \%$ sebesar 7,50\%; konsentrasi $80 \%$ sebesar $10,57 \%$ dan konsentrasi $100 \%$ sebesar 13,65\%.

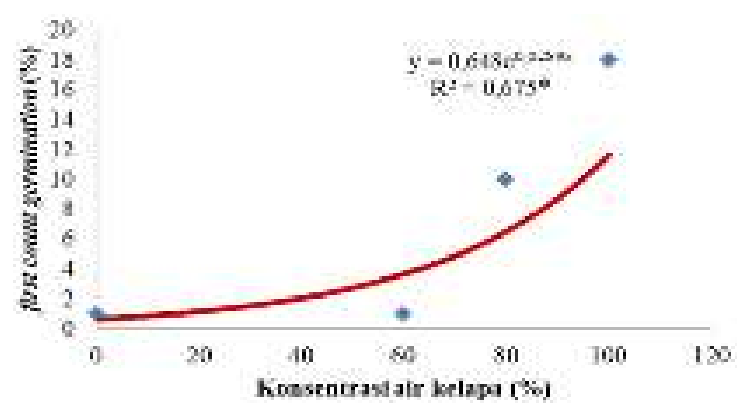

Gambar 2. Grafik Hubungan first count germination dengan konsentrasi air kelapa

\section{Potensi Tumbuh Maksimum (\%)}

Berdasarkan hasil rata-rata potensi tumbuh maksimum pada Tabel 5, menunjukkan bahwa perendaman benih dengan $\mathrm{KNO}_{3}$ yaitu dengan konsentrasi $\mathrm{K}_{3}(0,6 \%)$ tidak berbeda nyata dengan $\mathrm{K}_{2}(0,4 \%)$ dan berbeda nyata dengan $\mathrm{K}_{0}(0 \%)$ dan $\mathrm{K}_{1}$. Namun, nilai rata-rata tertinggi pada pengamatan persentase jumlah kecambah adalah perlakuan $\mathrm{K}_{3}(0,6 \%)$ sebesar $108 \%$. Hasil analisis regresi kuadratik konsentrasi $\mathrm{KNO}_{3}$ dan air kelapa terhadap potensi tumbuh maksimum disajikan dalam bentuk grafik yang dapat dilihat pada Gambar 3.

Tabel 1. Data hasil analisis setiap variabel pengamatan

\begin{tabular}{|c|c|c|c|c|c|c|c|c|}
\hline \multirow{2}{*}{\multicolumn{2}{|c|}{ Pexidiont }} & \multicolumn{7}{|c|}{ 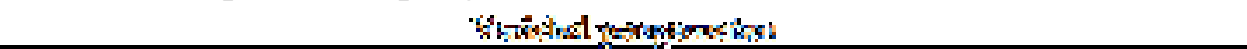 } \\
\hline & & 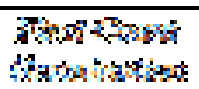 & 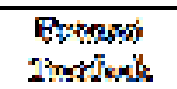 & 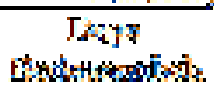 & 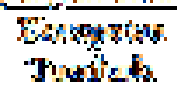 & $\begin{array}{l}\text { Fesjess } \\
\text { sutheds. }\end{array}$ & 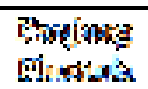 & $\begin{array}{l}\text { Torestest } \\
\text { lomasist? }\end{array}$ \\
\hline \multirow{4}{*}{ 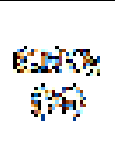 } & $\sin x y$ & 4,800 & 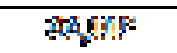 & 54 tyost & $x_{p} / x^{2}$ & $\operatorname{sigh}$ & $5,54 E_{2}$ & $2+3,14 \%$ \\
\hline & 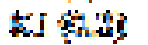 & *34 & Tisk & 4 & $\$, 11^{2}$ & +3. & j & 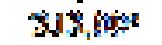 \\
\hline & 1564 & sing & jeweys" & Nhen & 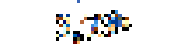 & 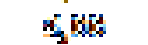 & 519 & rowers \\
\hline & 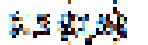 & I:Fif & $1+2=00.5$ & *arget & $s+20$ & $4 a^{2}$ & 375 & 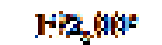 \\
\hline \multirow{4}{*}{ 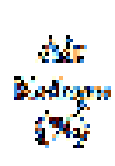 } & $\mathbf{F}_{9} \$$ & 1696" & ${ }^{2} \mathrm{WH}$ & 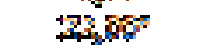 & $2,1 \%$ & 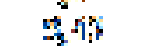 & 政 & 5856 \\
\hline & Foj jogy & $j_{0}, 20$ & 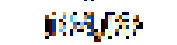 & $3 x_{0} n$ & 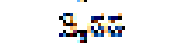 & 金然 & $2 \times$ & $19 m, w 5$ \\
\hline & Gets & consts & $\ln 2000$ & $\sin x$ & $9 * 36$ & $\underset{s i x}{4}$ & $x_{3}, \sqrt{y} y$ & Is istats \\
\hline & Fo intex: & $J r_{m}$ & $1+5 \times 3$ & 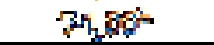 & $-1,03$ & sis & 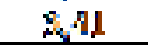 & $10 \mathrm{mos}$ \\
\hline
\end{tabular}

Keterangan: Angka yang diikuti huruf yang sama pada kolom dan baris yang sama, tidak berbeda nyata berdasarkan uji DMRT pada taraf $\alpha$ 5\%. 


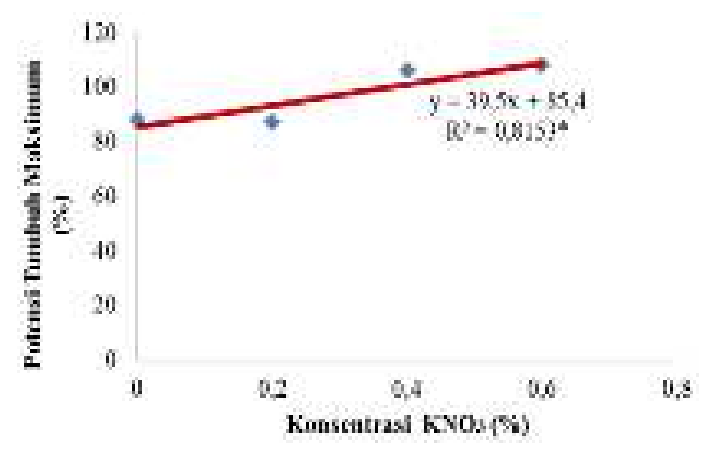

Gambar 3. Grafik Hubungan potensi tumbuh maksimum dengan konsentrasi $\mathrm{KNO}_{3}$

Hasil penelitian menunjukkan bahwa potensi tumbuh maksimum dengan perendaman $\mathrm{KNO}_{3}$ mengikuti persamaan $\mathrm{y}=39,5 \mathrm{x}+85,4$ dengan $\mathrm{R}^{2}=0,815$. Dari persamaan tersebut dapat dilihat bahwa sampai pada konsentrasi $0,6 \%$, setiap penambahan konsentrasi $\mathrm{KNO}_{3} 1$ $\%$ akan menaikkan 85,4 \% potensi tumbuh maksimum. Regresi ini menunjukkan bahwa peningkatan pemberian $\mathrm{KNO}_{3}$ dari konsentrasi $0 \%$ sampai $0,6 \%$ meningkatkan potensi tumbuh maksimum sebesar 81,5\% (gambar 3). Persamaan diatas dapat disubstitusikan dengan nilai konsentrasi $\mathrm{KNO}_{3} 0 \%$, bahwa pada konsentrasi tersebut diperkirakan nilai potensi tumbuh maksimum yaitu sebesar $85,4 \%$; pada konsentrasi 0,2\% sebesar 93,3\%; konsentrasi $0,4 \%$ sebesar 101,2 \% dan konsentrasi $0,6 \%$ sebesar 109, $1 \%$.

\section{Daya Berkecambah (\%)}

Berdasarkan hasil rata-rata daya kecambah pada Tabel 1, menunjukkan bahwa perendaman benih dengan $\mathrm{KNO}_{3}$ yaitu dengan konsentrasi $\mathrm{K}_{3}(0,6 \%)$ tidak berbeda nyata dengan $\mathrm{K}_{2}(0,4 \%)$ dan $\mathrm{K}_{1}(0,2 \%)$ dan berbeda nyata dengan $K_{0}(0 \%)$. Namun, nilai rata-rata tertinggi pada pengamatan daya berkecambah adalah perlakuan $\mathrm{K}_{3}(0,6 \%)$ sebesar $58 \%$. Hasil analisis regresi kuadratik konsentrasi $\mathrm{KNO}_{3}$ dan air kelapa terhadap daya berkecambah disajikan dalam bentuk grafik yang dapat dilihat pada Gambar 4 dan Gambar 5.

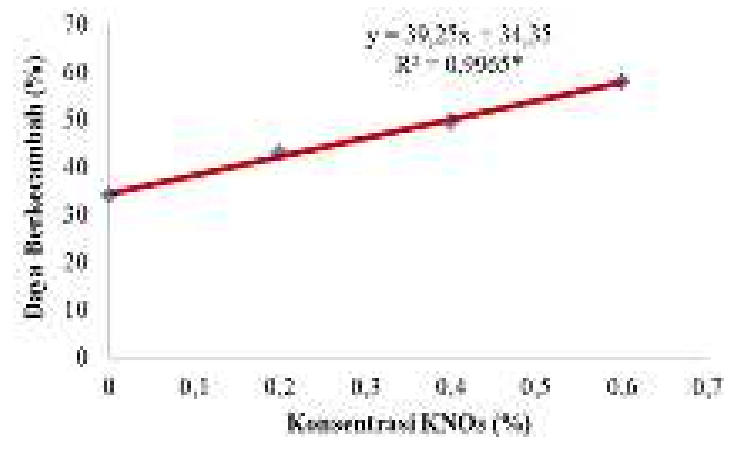

Gambar 4. Grafik Hubungan daya berkecambah dengan konsentrasi $\mathrm{KNO}_{3}$

Hasil penelitian menunjukkan bahwa daya berkecambah dengan perendaman $\mathrm{KNO}_{3}$ mengikuti persamaan $\mathrm{y}=39,2 \mathrm{x}+34,35$ dengan $\mathrm{R}^{2}=0,996$. Dari persamaan tersebut dapat dilihat bahwa setelah konsentrasi $0,6 \%$, setiap penambahan konsentrasi $\mathrm{KNO}_{3} 1 \%$ akan menaikkan 34,35 \% daya berkecambah. Regresi ini menunjukkan bahwa peningkatan pemberian $\mathrm{KNO}_{3}$ dari konsentrasi $0 \%$ sampai $0,6 \%$ meningkatkan daya berkecambah sebesar 99,6 \% (gambar 4). Persamaan diatas dapat disubstitusikan dengan nilai konsentrasi $\mathrm{KNO}_{3}$ $0 \%$, bahwa pada konsentrasi tersebut diperkirakan nilai daya berkecambah yaitu sebesar 34,35 \%; pada konsentrasi 0,2 \% sebesar 42,19\%; konsentrasi 0,4 \% sebesar $50,03 \%$ dan konsentrasi $0,6 \%$ sebesar 57,87 $\%$.

Faktor tunggal air kelapa yaitu $\mathrm{B}_{3}(100$ $\%)$ tidak berbeda nyata dengan $\mathrm{B}_{2}(80 \%)$ dan $\mathrm{B}_{1}(60 \%)$ dan berbeda nyata dengan $\mathrm{B}_{0}(0 \%)$. Namun, nilai rata-rata tertinggi pada pengamatan persentase jumlah kecambah adalah perlakuan $\mathrm{B}_{3}(100 \%)$ sebesar $74 \%$ dan terendah adalah pada perlakuan $\mathrm{B}_{0}$ sebesar 22 \%.

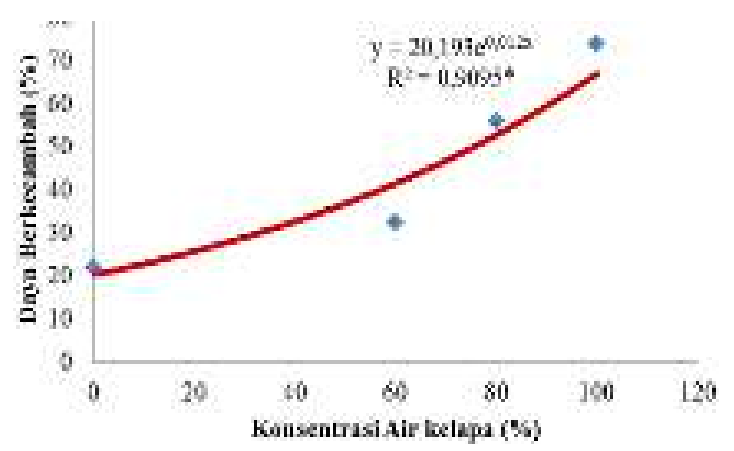

Gambar 5. Grafik Hubungan daya berkecambah dengan konsentrasi air kelapa 
Hasil penelitian menunjukkan bahwa daya berkecambah dengan perendaman air kelapa mengikuti persamaan $\mathrm{y}=20,19 \mathrm{e}^{0,012 \mathrm{x}}$ dengan $\mathrm{R}^{2}=0,9095$. Dari persamaan tersebut dapat dilihat bahwa setelah konsentrasi $0,6 \%$, setiap penambahan konsentrasi air kelapa $1 \%$ akan menaikkan 20,19\% daya berkecambah. Regresi ini menunjukkan bahwa peningkatan pemberian air kelapa dari konsentrasi $0 \%$ sampai $0,6 \%$ meningkatkan daya berkecambah sebesar 90,95\% (gambar 5). Persamaan diatas dapat disubstitusikan dengan nilai konsentrasi air kelapa $0 \%$, bahwa pada konsentrasi tersebut diperkirakan nilai daya berkecambah yaitu sebesar 20,19\%; pada konsentrasi $60 \%$ sebesar 46,07\%; konsentrasi $80 \%$ sebesar 55,91\% dan konsentrasi $100 \%$ sebesar $65,75 \%$.

\section{Kecepatan Tumbuh (\%/etmal)}

Berdasarkan hasil rata-rata kecepatan tumbuh pada Tabel 7, menunjukkan bahwa perendaman benih dengan $\mathrm{KNO}_{3}$ yaitu dengan konsentrasi $\mathrm{K}_{3}(0,6 \%)$ tidak berbeda nyata dengan $\mathrm{K}_{2}(0,4 \%)$ dan berbeda nyata dengan $\mathrm{K}_{0} \quad\left(\begin{array}{ll}0 & \%\end{array}\right)$ dan $\mathrm{K}_{1}$. Hasil analisis regresi kuadratik konsentrasi $\mathrm{KNO}_{3}$ terhadap kecepatan tumbuh disajikan dalam bentuk grafik yang dapat dilihat pada Gambar 6 .

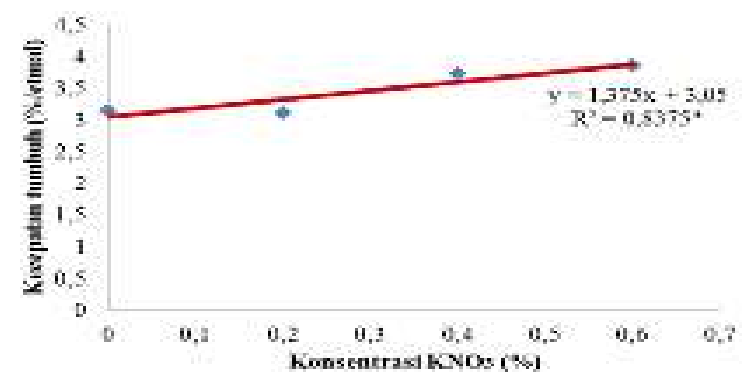

Gambar 6. Grafik Hubungan kecepatan tumbuh dengan konsentrasi $\mathrm{KNO}_{3}$

Hasil penelitian menunjukkan bahwa kecepatan tumbuh dengan perendaman $\mathrm{KNO}_{3}$ mengikuti persamaan $\mathrm{y}=1,375 \mathrm{x}+3,05$ dengan $\mathrm{R}^{2}=0,83$. Dari persamaan tersebut dapat dilihat bahwa setelah konsentrasi $0,6 \%$, setiap penambahan konsentrasi $\mathrm{KNO}_{3} \quad 1 \%$ akan menaikkan 3,05\% kecepatan tumbuh. Regresi ini menunjukkan bahwa peningkatan pemberian $\mathrm{KNO}_{3}$ dari konsentrasi $0 \quad \%$ sampai $0,6 \%$ meningkatkan kecepatan tumbuh sebesar 83,7 $\%$ (gambar 6). Persamaan diatas dapat disubstitusikan dengan nilai konsentrasi $\mathrm{KNO}_{3}$ $0 \%$, bahwa pada konsentrasi tersebut diperkirakan nilai kecepatan tumbuh yaitu sebesar 3,05\%; pada konsentrasi 0,2 \% sebesar $3,32 \%$; konsentrasi $0,4 \%$ sebesar 3,6 \% dan konsentrasi $0,6 \%$ sebesar $3,87 \%$.

\section{Panjang Radikula (cm)}

Kombinasi perlakuan pemberian $\mathrm{KNO} 3$ dan air kelapa tidak berbeda nyata terhadap panjang radikula benih kelapa sawit, panjang radikula tertinggi yaitu $7,25 \mathrm{~cm}$ pada perlakuan skarifikasi dengan KNO3 $0,2 \%$ (K1B0). Panjang radikula terendah pada perlakuan pemberian KNO3 dan air kelapa 0,2\% (K0B1) yaitu $2,00 \mathrm{~cm}$.

\section{Panjang Plumula (cm)}

Kombinasi perlakuan pemberian $\mathrm{KNO} 3$ dan air kelapa tidak berbeda nyata terhadap panjang plumula benih kelapa sawit, panjang plumula tertinggi yaitu $7,25 \mathrm{~cm}$ pada perlakuan skarifikasi dengan KNO3 $0 \%$ (K0B3). Panjang plumula terendah pada perlakuan pemberian KNO3 dan air kelapa 0,4 \% (K2B1) yaitu 1,97 $\mathrm{cm}$.

\section{Intensitas Dormansi (\%)}

Berdasarkan hasil rata-rata intensitas dormansi pada Tabel 1, menunjukkan bahwa perendaman benih dengan $\mathrm{KNO}_{3}$ yaitu dengan konsentrasi $\mathrm{K}_{1}(0,2 \%)$ berbeda nyata dengan $\mathrm{K}_{2}(0,4 \%), \mathrm{K}_{3}(0,6 \%)$ dan berbeda tidak nyata

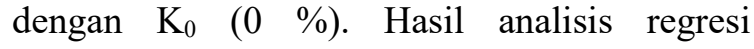
kuadratik konsentrasi $\mathrm{KNO}_{3}$ dan air kelapa terhadap intensitas dormansi disajikan dalam bentuk grafik yang dapat dilihat pada Gambar 7 dan Gambar 8.

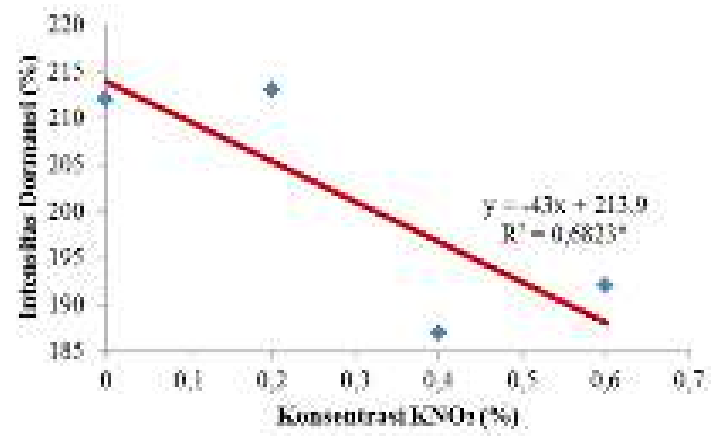

Gambar 7. Grafik Hubungan intensitas dormansi dengan konsentrasi $\mathrm{KNO}_{3}$ 
Hasil penelitian menunjukkan bahwa intensitas dormansi dengan perendaman $\mathrm{KNO}_{3}$ mengikuti persamaan $y=-43 x+213,9$ dengan $\mathrm{R}^{2}=0,68$. Dari persamaan tersebut dapat dilihat bahwa setelah konsentrasi $0,6 \%$, setiap pengurangan konsentrasi $\mathrm{KNO}_{3} \quad 1 \%$ akan menaikkan 213,9 \% intensitas dormansi. Regresi ini menunjukkan bahwa peningkatan pemberian $\mathrm{KNO}_{3}$ dari konsentrasi $0 \%$ sampai $0,6 \%$ menurunkan intensitas dormansi sebesar $68,23 \%$ (gambar 7). Persamaan diatas dapat disubstitusikan dengan nilai konsentrasi $\mathrm{KNO}_{3}$ $0 \%$, bahwa pada konsentrasi tersebut diperkirakan nilai intensitas dormansi yaitu sebesar 213,9 \%; pada konsentrasi 0,2 \% sebesar 205,3\%; konsentrasi $0,4 \%$ sebesar $196,7 \%$ dan konsentrasi 0,6 \% sebesar 188,1 $\%$.

Berdasarkan hasil
intensitas dormansi pada Tabel 1, menunjukkan bahwa perendaman benih dengan air kelapa yaitu dengan konsentrasi $\mathrm{B}_{0}(0 \%)$ berbeda nyata dengan $\mathrm{B}_{1}(60 \%)$, $\mathrm{B}_{2}(80 \%)$ dan $\mathrm{B}_{3}(0 \%)$. Namun, nilai ratarata tertinggi pada pengamatan intensitas dormansi adalah perlakuan $\mathrm{B}_{0}(0 \%)$ sebesar $233 \%$.

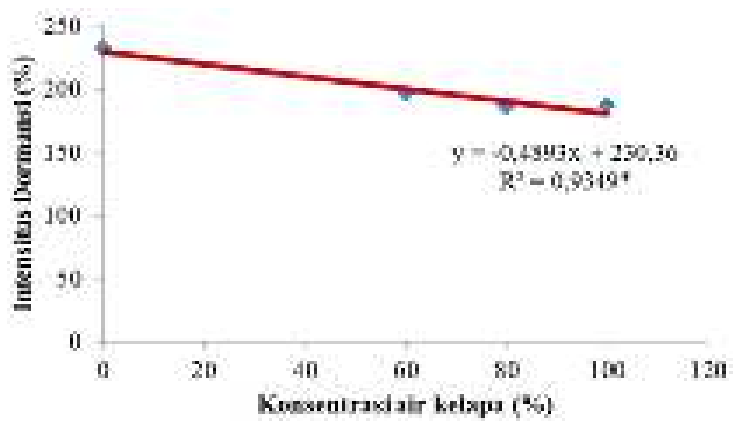

Gambar 8. Grafik Hubungan intensitas dormansi dengan konsentrasi air kelapa

Hasil penelitian menunjukkan bahwa intensitas dormansi dengan perendaman $\mathrm{KNO}_{3}$ mengikuti persamaan $\mathrm{y}=-43 \mathrm{x}+213,9$ dengan $\mathrm{R}^{2}=0,68$. Dari persamaan tersebut dapat dilihat bahwa setelah konsentrasi $0,6 \%$, setiap pengurangan konsentrasi $\mathrm{KNO}_{3} \quad 1 \%$ akan menaikkan 213,9 \% intensitas dormansi. Regresi ini menunjukkan bahwa peningkatan pemberian $\mathrm{KNO}_{3}$ dari konsentrasi $0 \%$ sampai $0,6 \%$ menurunkan intensitas dormansi sebesar
$68,23 \%$ (gambar 8). Persamaan diatas dapat disubstitusikan dengan nilai konsentrasi $\mathrm{KNO}_{3}$ $0 \%$, bahwa pada konsentrasi tersebut diperkirakan nilai intensitas dormansi yaitu sebesar 213,9 \%; pada konsentrasi 0,2 \% sebesar 205,3 \%; konsentrasi $0,4 \%$ sebesar $196,7 \%$ dan konsentrasi $0,6 \%$ sebesar 188,1 $\%$.

Hasil rata-rata persentase jumlah kecambah menunjukkan bahwa perlakuan $\mathrm{K}_{3}$ $(0,6 \%)$ memberikan hasil rata-rata tertinggi terhadap semua variabel pengamatan. Hal ini diduga bahwa bahan kimia $\mathrm{KNO}_{3}$ dapat mengoksidasi kulit benih dan akan melunakkan kulit benih, sehingga akan memudahkan masuknya air pada waktu proses imbibisi. Sejalan dengan penyerapan air, maka oksigen terlarutpun ikut terbawa, hal ini memungkinkan lebih aktifnya proses respirasi dimana sebelumnya bahwa benih kelapa sawit merupakan benih yang sulit untuk berkecambah. Mulai dari kulit benih yang begitu keras, impermeable terhadap air dan gas, dan hormon yang ada didalam benih itu sendiri. Semakin tinggi konsentrasi $\mathrm{KNO}_{3}$ maka semakin mempercepat proses perkecambahan benih kelapa sawit. Menurut Ellery dan Chapman (2000), perlakuan dengan bahan kimia untuk mematahkan dormansi benih tujuannya adalah menjadikan agar kulit benih lebih mudah dimasuki oleh air pada waktu proses imbisisi. Bahan kimia tersebut membuat kulit benih menjadi lunak sehingga dapat dilakui oleh masuknya air dengan mudah.

Semakin tinggi konsentrasi $\mathrm{KNO}_{3}$ yang diberikan maka semakin efektif pematahan dormansi benih. Hal ini sesuai dengan pernyataan Faustina et al., (2011) yang menyatakan bahwa salah satu larutan kimia untuk mematahkan dormansi adalah $\mathrm{KNO}_{3}$, larutan $\mathrm{KNO}_{3}$ juga sudah teruji efektif mematahkan dormansi beberapa benih tanaman, antara lain padi dan aren. $\mathrm{KNO}_{3}$ berfungsi untuk meningkatkan aktifitas hormon pertumbuhan pada benih dan menjadikan kulit benih lebih mudah dimasuki air pada waktu proses imbibisi. Pengaruh $\mathrm{KNO}_{3}$ yang ditimbulkan ditentukan oleh besar kecil konsentrasinya.Perlakuan awal dengan larutan $\mathrm{KNO}_{3}$ berperan merangsang perkecambahan pada hampir seluruh jenis biji. Perlakuan perendaman dalam larutan $\mathrm{KNO}_{3}$ dilaporkan 
juga dapat mengaktifkan metabolisme sel dan mempercepat perkecambahan.

Perlakuan perendaman air kelapa menghasilkan nilai rata-rata tertinggi pada pengamatan persentase jumlah kecambah adalah perlakuan $\mathrm{B}_{3}(100 \%)$ sebesar $74 \%$ dan terendah adalah pada perlakuan $\mathrm{B}_{0}$ sebesar 22 $\%$. Hal ini dikarenakan air kelapa muda adalah salah satu zat pengatur tumbuh yang mengandung auksin dan sitokinin yang diperlukan untuk perkembangan dan pertumbuhan tanaman. Hal ini sesuai dengan pernyataan Fanesa (2011) yang menyatakan bahwa air kelapa muda adalah salah satu zat pengatur tumbuh yang mengandung auksin dan sitokinin yang diperlukan untuk perkembangan dan pertumbuhan tanaman. Menurut penelitian Fahmi (2008), air kelapa muda 25\% merupakan zat pengatur tumbuh yang tepat dan terbaik yang dapat merangsang pertumbuhan tunas dasar buah nenas.

Hal ini dikarenakan pemberian air kelapa dengan konsentrasi $100 \%$ dapat menghasilkan persentase perkecambahan yang tinggi dan persentase kecepatan tumbuh yang tinggi pula. Hal ini sesuai dengan pernyataan Hedty et al (2014) yang menyatakan bahwa Perendaman biji kopi dengan air kelapa menghasilkan persentase perkecambahan yang tinggi dan persentase kecepatan tumbuh yang tinggi pula. Peningkatan konsentrasi air kelapa dari $0 \%, 60$ $\%$, $80 \%$, dan $100 \%$ secara linear juga meningkatkan persentase perkecambahan..

\section{KESIMPULAN}

1. Perlakuan $\mathrm{KNO}_{3}$ dan air kelapa menunjukkan tidak terjadi interaksi pada semua variabel pengamatan yang meliputi persentase jumlah kecambah (first count germination), potensi tumbuh maksimum,daya berkecambah, kecepatan tumbuh, panjang radikula, panjang plumula dan intensitas dormansi.

2. Perlakuan $\mathrm{KNO}_{3}$ dengan konsentrasi $0,6 \%$ mampu memberikan hasil perkecambahan benih kelapa sawit yang lebih baik yaitu pada variabel persentase jumlah kecambah (first count germination) sebesar $12 \%$, potensi tumbuh maksimum sebesar $108 \%$, daya kecambah sebesar $58 \%$, kecepatan tumbuh sebesar 3,86\%/etmal dan intensitas dormansi sebesar $188 \%$.

3. Perlakuan air kelapa dengan konsentrasi $100 \%$ mampu memberikan hasil perkecambahan benih kelapa sawit yang lebih baik yaitu pada variabel persentase jumlah kecambah (first count germination) sebesar $18 \%$, daya berkecambah sebesar 74 $\%$ dan intensitas dormansi sebesar $192 \%$.

\section{SARAN}

Biji kelapa sawit merupakan biji rekalsitran yang mempunyai kadar air tinggi, maka untuk penelitian selanjutnya perlu dilakukan pengukuran kadar air sebelum perlakuan perendaman untuk mengetahui dan mempertahankan kadar air yang sesuai untuk perkecambahan benih kelapa sawit dan untuk mempertahankan viabilitas benih.

\section{DAFTAR PUSTAKA}

Badan Pusat Statistik. 2017. Statistik Kelapa Sawit Indonesia 2017. https://www.bps.go.id/publication. [13 November 2018].

Fahmi, Z.I. Studi teknik Pematahan Dormansi dan Media Perkecambahan Terhadap Viabilitas Benih Aren (Arenga pinnata (Wurmb.) Merr). Balai Besar Perbenihan Perkebunan dan Proteksi tanaman Perkebunan Surabaya

Fanesa, A. 2011. Pengaruh Pemberian Beberapa Zat Pengatur Tumbuh Terhadap Pertumbuhan Setek Pucuk Jeruk Kacang (Citrus nobilis L.). Jurnal Pastura.1(1): 5-8.

Farhana, B., S. Ilyas., L.F. Budiman. 2013. Pematahan Dormansi Benih Kelapa Sawit (Elaeis guineensis Jacq.) Dengan Perendaman Dalam Air Panas Dan Variasi Konsentrasi Ethephon. Jurnal Agrohorti 1. Fakultas Pertanian Institut Pertanian Bogor. Bogor. vol 1, (1) :7278.

Faustina E., Prapto Yudono, Rohmanti R. 2011.Pengaruh Cara Pelepasan Arildan Konsentrasi $\mathrm{KNO}_{3} \quad$ Terhadap Pematahan Dormansi Benih Pepaya (Carica papaya L.) Skripsi. Universitas Gadjah Mada, Yogyakarta.

Hedty, Mukarlina, Masnur Turnip. 2014. Pemberian $\mathrm{H}_{2} \mathrm{SO}_{4}$ dan Air Kelapa pada 
Uji Viabilitas Biji Kopi Arabika

(Coffea arabika L.) Jurnal Protobiont. 3

(1): 7-11.

Lawalata dan Jeanette I. 2011. Pemberian

Beberapa Kombinasi ZPT terhadap

Regerasi Tanaman Gloxinia dari

Eksplan Batang dan Daun Secara In

Vitro. J Exp. Life Sci. 1 (2) :83-87.

Mangoensoekarjo, S. dan Semangun H. 2005.

Manajemen Agrobisnis Kelapa Sawit.

Gadjah Mada Unversity Press. Yogyakarta.

Masykur. 2013. Pengembangan Industri

Kelapa Sawit Sebagai Energi Bahan

Bakar Alternatif danMengurangi

Pemanasan Global. Jurnal Reformasi, Vol. 3, No. 2, Juli - Desember.

Saputra, D., E. Zuhry., S. Yosefa. 2017. Pematahan Dormansi Benih Kelapa Sawit (Elaeis guineensis Jacq.) Dengan Berbagai Konsentrasi Kalium Nitrat $\left(\mathrm{KNO}_{3}\right)$ Dan Pengaruhnya Terhadap Pertumbuhan Bibit Pada Tahap Pre Nursery. Jurnal Online Mahasiswa. Fakultas Pertanian, Universitas Riau.Pekanbaru. VOL.4 NO 2: Oktober 2017 